\title{
What Determines Balance of Payments: A Case of Pakistan
}

\author{
Syeda Azra Batool*1 \\ Bahauddin Zakariya University, Multan Pakistan \\ Tahir Memood ${ }^{2}$ \\ University of Punjab, Lahore Pakistan \\ Atif Khan Jadoon ${ }^{3}$ \\ University of Punjab, Lahore Pakistan
}

\begin{abstract}
:
Distortion in balance of payments is one of the dominant causes for the sluggish economic condition of Pakistan. The present article has focused to scrutinize the relationship of the balance of payments to its certain determinants that are actually blamable or not for its distortion. The robust ARDL structure has been utilized to develop the bound testing approach to co-integration and error correction models on data set for 1972-2013. The bound test declares that there exists stable long run relationship of balance of payments to its determinants. The upshots indicate that real exchange rate inversely influences the balance of payments not only in the long run but also in the short run. Interest rate inversely affects the balance of payment in the long run but positively affects in the short run.Fiscal balance affects the BOP negatively in the long and short run simultaneously. As regards the real GDP, it moves the BOP in the positive direction in both long and short run. The money supply cast positive influence on the BOP in the short run but negative effect in the long run. So the need of the hour is that the real GDP of Pakistan should be increased by the deliberate policy of the government. Because it is the GDP that can increase our savings consumption and government expenditures and exports and can improve balance of balance of payment.
\end{abstract}

Keywords: Balance of Payments (BOP), Money Supply, Real Exchange Rate, Real GDP, Interest Rate and Fiscal Balance.

https://doi.org/10.30537/sijmb.v2i1.88

*Email: azrabatools@yahoo.com 


\section{Introduction}

There are so many factors that are responsible for the horrendous economic condition of developing economies. Balance of payment of a country manifests how much a country is advanced and technologically developed. The stability in balance of payments accounts is related to the economic growth of the country. Equilibrium in balance of payments indicates a sound economic position of a country distortion in it indicates unsatisfactory economic position of a country. Many countries of the world including Pakistan are experiencing the phenomenon of deficit in BOP.

The trend analysis shows that most of the times overall balance of payments has remained in deficit in case of Pakistan. This arises many questions on the potential of the economy of Pakistan and as well as causes of imbalance in BOP. The international financial organizations like IMF and World Bank reiterate to stabilize BOP situation in Pakistan.

In 2008, Pakistan deterred a balance of payments problem by securing amount of $\$ 11$ billion IMF loan package. The IMF suspended the program in 2011 when economic targets were missed. Some analysts warned about the prospect of a new balance of payments crisis. Hence they anticipated that Pakistan would have to go back to IMF for another bailout to avoid a new crisis. The ADB, along with IMF, has been pushing Pakistan's government to accomplish politically-sensitive reforms to fortify the economy and broaden the country's revenue base. At the moment, Pakistan is indebted to IMF just over $\$ 6.2$ billion. It has to make big repayment in the first six months of 2013, a schedule that will pressure reserves and may fast-track the slide of Pakistani rupee. This crisis in BOP is the very justification for the present study. What does affect the BOP in Pakistan and in what direction remains the focus of the study?

Balance of payments is a record-keeping book which shows the international transaction of the resident country with the rest of the world any transaction payments to the foreigners are entered into the balance of payments account as a debit with negative sign whereas a receipt from the foreigners is entered into the balance of payments accounts as a credit with a positive sign (Krugman 1998). Every transaction automatically enters the balance of payments twice, once as credit and second as debit. So, balance of payments is called a double entry bookkeeping record.

There are three approaches to analyze the balance of payments. First is, Elasticity Approach: presented by (Robinsen 1937). It states that devaluation in the currency improves the balance of payment if the price elasticity of domestic and foreign demand of imports is greater than one. Marshal- Lerner condition and J-curve effect are used in this approach. 
Second is Absorption Approach presented by (Alexander 1952); this approach is used to look at the balance of trade account from the point of view of national income accounting. So, this approach is a difference of national income receipt and domestic absorption as depicted in equation $\mathrm{Y}=\mathrm{A}+(\mathrm{X}-\mathrm{M})$ where $\mathrm{A}=\mathrm{C}+\mathrm{I}$ where $(\mathrm{X}-\mathrm{M})$ is exports minus imports, $\mathrm{C}$ and means consumption and investment respectively. (Mundel 1971); Points out that balance of payments is a monetary phenomenon and the disequilibrium in the balance of payments can be corrected with the help of international reserves. This approach implies that there is a negative relationship between domestic credit and foreign reserves.

Despite the fact there are mainly three approaches for balance of payments but the present study is an empirical effort to take the determinants of balance of payments with General Approach (an approach that includes monetary absorption and elasticity approach variables simultaneously but no particular approach out of three). For this purpose new econometric technique autoregressive distributed lag model (ARDL) is used. In this research, money supply, interest rate and real gross domestic product are set as main determinants of BOP.

Plan of the study is as follows: The first part is regarding the background of the study and statement of the problem, has already been done. The rest of the plan of the study is as follows: The second part reviews the earlier studies on determinants of balance of payments. The third part describes the data and methodology to be used to find the empirical results. The fourth part carries the general approach to balance of payments, its estimation and results following policy implication.

Several studies have worked on the balance of payments and economic growth. These studies show that equilibrium in the balance of payments is a key component in economic growth.

Figure 1: Overall Balance of Payment Position of Pakistan (Million Rs)

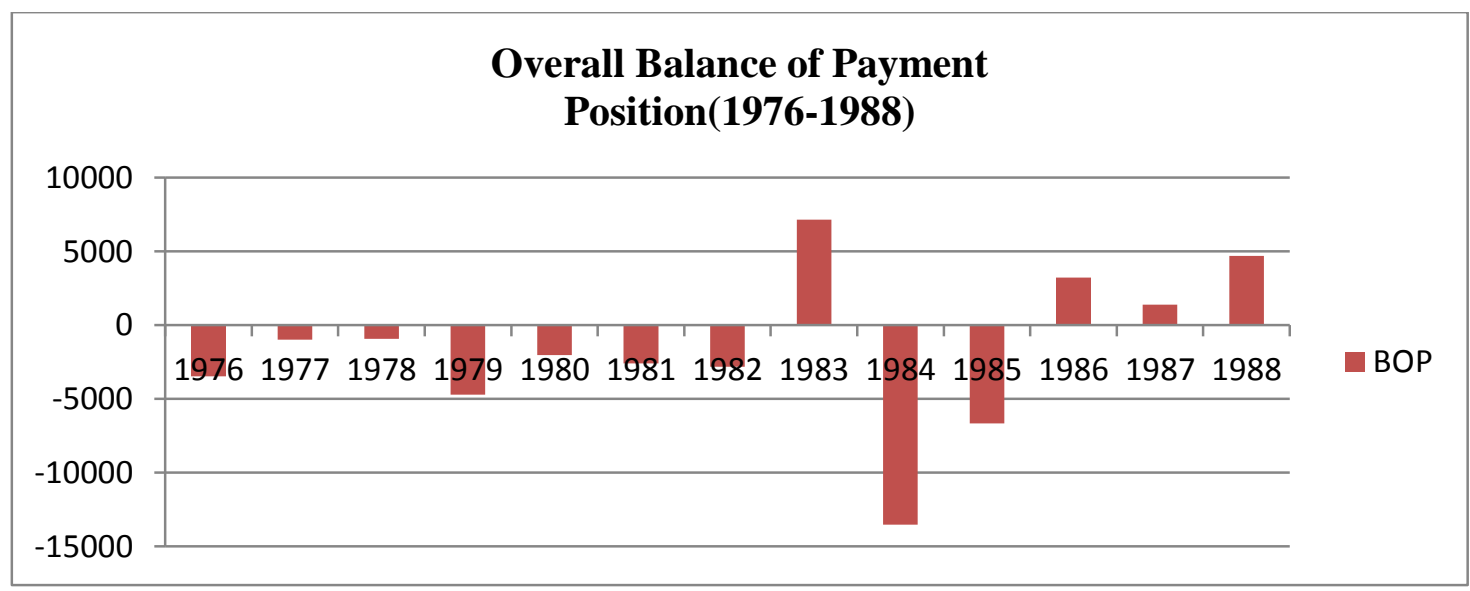

Sources: State Bank of Pakistan, International Financial Statistics, Pakistan Economic Survey. 
Figure 2: Overall Balance of Payment Position of Pakistan (Million Rs.)

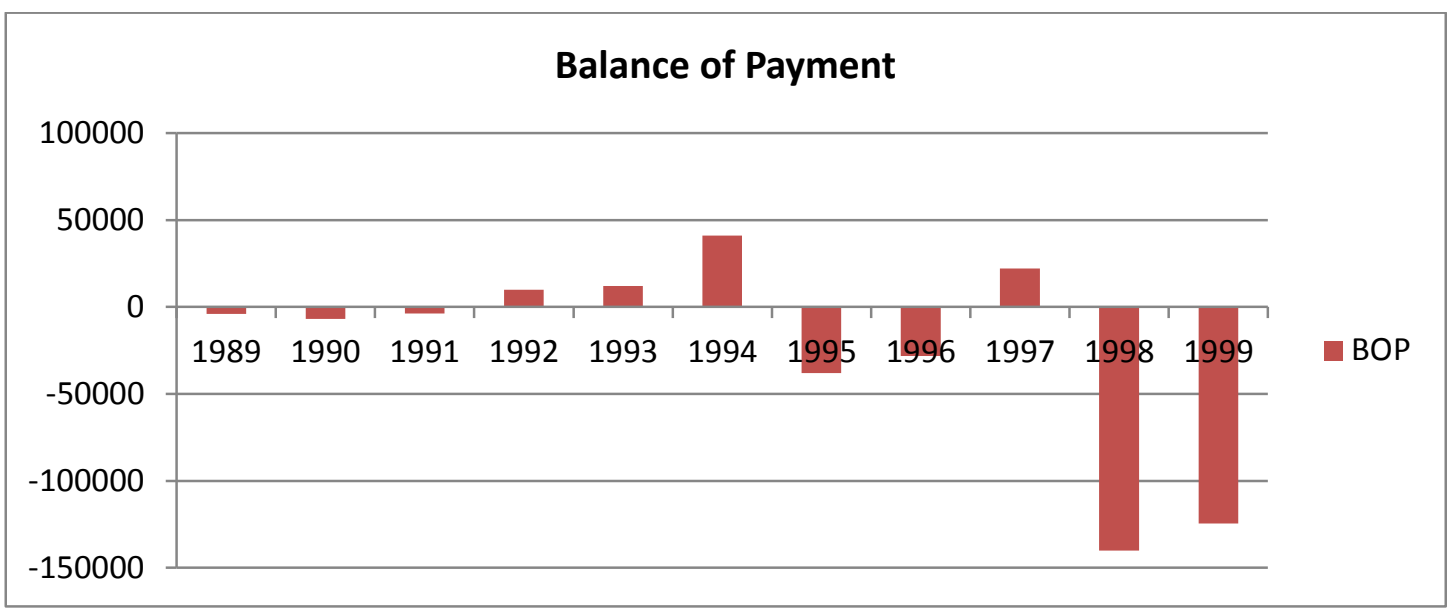

Sources: State Bank of Pakistan, International Financial Statistics, Pakistan Economic Survey

Figures 1 and 2 and 3, have depicted different periods. Every government adopted many different fiscal and monetary policies as far as its international transaction was concerned. But, every time, Pakistan balance of payment remained in deficit except these years 194748, 1950-51 and 1971-72. The deficit not only caused a domestic debt but also foreign debt. This total debt remained a big hurdle in the way of economic development. Overall balance of payments position deficit was highest in 2008 .

Figure 3: Overall Balance of Payment Position of Pakistan (Million Rs.)

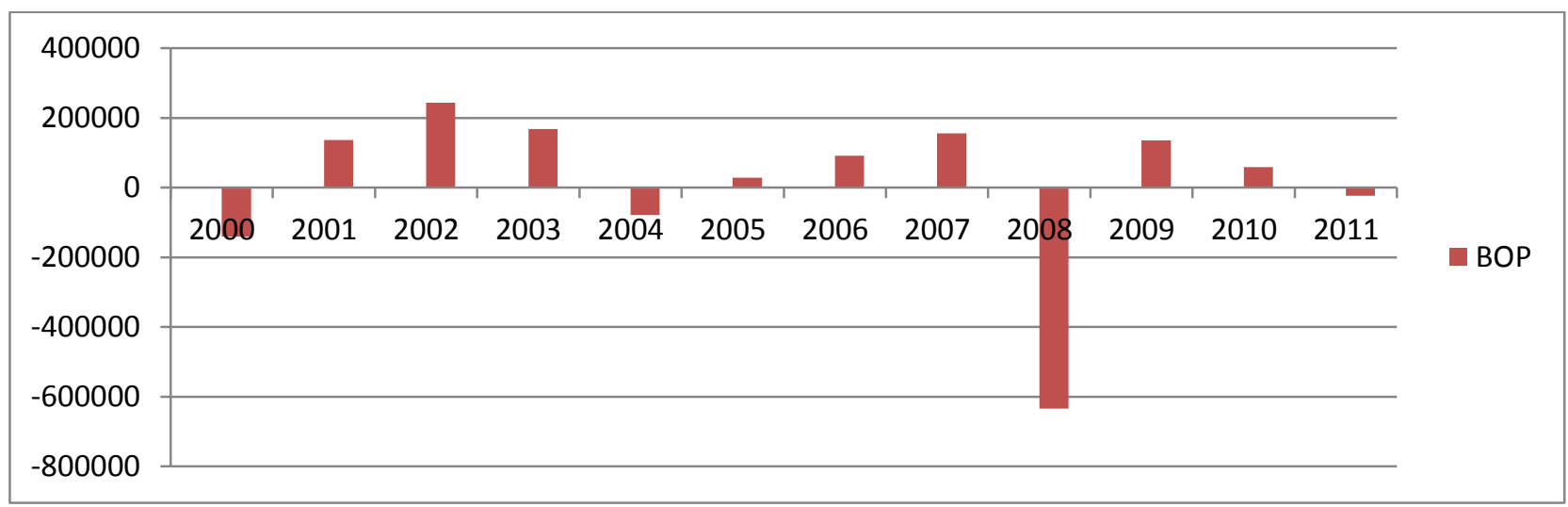

Sources: State Bank of Pakistan, International Financial Statistics, Pakistan Economic Survey. 


\section{Review of Literature}

In order to find the determinants of balance of payments, a host of studies have already been done. Some of the studies are related to Pakistan while others to rest of the world. Various economists have worked on the determinants of balance of payments and they have used different approaches like absorption approach, elasticity approach and monetary approach in order to observe the effect of the determinants of balance of payments in case of Pakistan.

(Chaudhary and Shabbir 2005); found that price level and real income were positively related whereas interest rate, inflation rate, money multiplier and domestic credit were negatively related to foreign exchange reserves and significant. They found that fiscal deficit financing through domestic credit creation was harmful and would cause the reduction in foreign reserves. They concluded that monetary approach to the balance of payments was not a good approach. (Khan 2008); found that income and real exchange rate were positively whereas interest rate and domestic credit were negatively related to foreign reserves and significant in short run. But in the long run income and exchange rate positively related to foreign reserves and interest rate and domestic credit were negatively related to foreign reserves. (Felipe et.al 2009); using ARDL model found that real effective exchange rate and money supply were negatively related to imports whereas Income and Real effective exchange rate were positively related to imports and significance in case of Pakistan.

(Fida et.al 2009); found that during 1955-1980 and 1955-1989 import elasticity in Pakistan was increased by $1.31 \%$ whereas in 1975-1995 and 1975-2005, when economy was more open, elasticity was increased by $3.30 \%$. Umar et.al (2010) used the monetary approach in case of Pakistan. They used the co-integration and error correction modeling (ECM) and found that coefficients of interest rate and domestic credit were negatively related to foreign assets and significance. GDP was found to be positively related to foreign assets and significant. But the co-efficient of inflation rate was statistically insignificant and had no effect on balance of payments.

(Waliullah et.al 2010); using the bounds testing approach to co-integration and error correction model developed in ARDL framework found that coefficients of income and exchange rate were positive and significant both in short as well as long run. Whereas the coefficient of money supply was found to be negative both in short and long run. (Mohammad 2010); found, as far as foreign income increased it lessened the trade deficit. The coefficient of real effective exchange rate (REER) was positive and significant as REER depreciated it increased the balance of trade. The co-efficient of foreign direct investment (FDI) was positive and statistically significant. The co-efficient of household domestic spending was negatively and statistically significant. 
(Ali 2011); using co-integration and error-correction modeling observed that net foreign assets, exchange rate and inflation rate positively whereas money supply and domestic credit were negatively related to balance of payments and significant. Interest rate was found to be insignificant and negative. He further declared that balance of payments as a monetary phenomenon was not the good criteria because other factors also affected the balance of payments.

(Baluch and Bukhari 2012); explained the price and income elasticity of imports in case of Pakistan by using the ARDL model and found that 1 percent increase in income caused the 1.22 percent increase in imports whereas as 1 percent increase in prices caused the 0.53 percent decrease in imports.

(Dhliwayo 1996); found that income and price level were positively related to international reserves inflow and significance whereas interest rate and domestic credit were positively related to international reserves outflow and significance in the long run in Zimbabwe. The study found that income, interest rate and domestic credit were negatively related to international reserves inflow and price level were found to be positively related to international reserves and significance in the short run.

(Hernan 1998); found that GDP and exchange rate positively affected the trade balance and significant whereas money supply was negatively related to trade balance in the long run in case of Colombia. In the short run GDP and exchange rate positively whereas money supply negatively affected the trade balance and significant in the short run.

(Fleermuys 2005); concluded that monetary approach would not be the appropriate approach for balance of payments in case of Namibia. It was found that coefficients of log of GDP and inflation rate were positive and significant and coefficients of interest rate and log of domestic credit were negative and significant.

(Duasa 2004); utilized the bound-testing approach to co-integration and error correction modeling developed within the ARDL framework in case of Malaysia. It was found that in the long run money supply was negatively but income was positively related to trade balance. Marshall Lerner condition did not hold in case of Malaysia .It showed that in short run increase in income worsened the trade balance with the increase in imports.

(Rano et.al 2008); worked on the import-export demand functions and its effects on Nigerian balance of payments, utilizing the co-integration and error correction modeling (ECM). It was found that coefficients of GDP, foreign reserves and index of openness positive and significant. Whereas the coefficients of exchange rate and import capacity were negative and insignificant. As far as export demand function was concerned, it was found 
that coefficients of exchange rate, index of openness were positive and significant, whereas coefficient of GDP was negative and significant.

(Alvarez-Ude et.al 2008); found the empirical evidence of the balance of payments constrained growth in Cuba using the Co-integration multivariate test and proved the Thirlwall's model in case of Cuba with exports and imports related positively to GDP.

(Falk 2008); working on panel data, using fixed effects and linear mixed models , found that real foreign GDP per capita was positively related whereas domestic GDP per capita was negatively related to trade balance and significance. It was also seen that devaluation in real effective exchange rate and foreign direct investment improved the trade balance.

(Trunin 2012); using the vector auto regression model has found that GDP, exchange rate, inflation rate, money supply and portfolio investment were positively related to capital inflow and significant.

(Korsu 2009); empirically worked on fiscal deficit and external sector performance of Sierra Leone. He used the three stages least squares (3SLS) method and found that exchange rate and income were positively related to balance of payments and significant. Whereas price level and interest rate were negatively related to balance of payments and significant.

(Adamu and Itsede 2010); used the monetary approach to the balance of payments in West African Monetary Zone, by taking panel data, using the generalized methods of moments (GMM) estimation technique within the country and cross country effects. It was found that GDP was positively related to net foreign assets. The co-efficient of domestic credit was negative and statistically significant. Interest rate was found to be negatively related to net foreign assets and inflation rate was found to be insignificant and negligibly affected the balance of payments.

(Eita 2012); found that fiscal balance, GDP growth rate and interest were the main determinants of balance of payments in Namibia. The co-efficient of exchange rate found to be insignificant. The co-efficient of GDP, interest rate and Fiscal balance were positive and statistically significant.

The above literature has disclosed that bank credit, nominal exchange rate, foreign direct investment, foreign exchange reserves, growth rate, inflation rate, money supply, External debt, interest rate, domestic credit, trade openness and real GDP growth rate were used as the determinants of balance of payments outside Pakistan whereas in case of Pakistan money supply, net foreign assets, exchange rate, inflation rate, interest rate, foreign direct investment were used as the main determinants of balance of payments. 
The previous literature tackled the determinants of balance of payments with Absorption approach or Monetary approach or Elasticity approach but none of the study was done on general approach ,that does not refers to any particular approach stated above rather utilizes mix set of variables of all approaches to see their effect on BOP. As it has been proved by various studies that monetary approach was not good. Similarly every approach uses specific set of determinants of balance of payment explicitly ignoring the other approach's factors. So present study is an effort to use some combination of factors so that effect of such determinants can be observed in a unique way. In order to cover this gap we have found out five major determinants namely real exchange rate, interest rate, money supply (M1), fiscal balance and real gross domestic product.

Different researchers utilized different econometric techniques e.g. (Johansen Jeselius 1990), OLS, (Engle-Granger 1987) etc. The present study has an edge over the previous studies in that new econometric technique autoregressive distributed lag((ARDL)) model has been utilized in order to analyze the determinants of balance of payments under general approach to the determinants of BOP. Furthermore, this study has been done on the up to date available data (2011).

The major determinants of balance of payments to be used in the present study would be real exchange rate, interest rate, money supply (M1), fiscal balance and real gross domestic product. If these variables are efficiently managed by any country its overall balance of payments will be improved.

\section{Methodology and Data Sources}

In this study annual time series data is used for the period of 1972 to 2013 . The data has been collected from Hand book of statistics on Pakistan economy, 50 year of statistics on Pakistan economy, Economic survey of Pakistan, International Financial Statistics and International Monetary Fund.

Empirically exploring the main determinants of balance of payments in Pakistan by estimating the model that may help the long run and short run behavior of such determinants is set as the objective of the present study. The three different theories mentioned earlier demonstrate that a country's balance of payments may be affected by changes in the GDP, money supply, and exchange rate etc. Making use of all three theoretical background, the present study is an effort to develop a model that integrates all three approaches simultaneously and uses it to analyze Pakistan's balance of payment. The justification for including all three approaches in a single equation model is to verify their empirical implication and validity and minimize the residual unexplained variation in the balance of payments model. 
Model for General Approach to BOP will be formed and presented by the following equation is as

$$
\mathrm{BOP}=\alpha_{0}+\alpha_{1} \mathrm{M} 1+\alpha_{2} \mathrm{RER}+\alpha_{3} \mathrm{IR}+\alpha_{4} \mathrm{FB}+\alpha_{5} \mathrm{RGDP}+\varepsilon_{\mathrm{t}}
$$

Where

$\left(\alpha_{1}, \alpha_{2}, \alpha_{3}, \alpha_{4}\right.$ and $\alpha_{5}$ are coefficients), BOP = Balance of Payments., $\alpha 0$ is the intercept term

M1 = Money Supply(is the sum of currency held by people, held by banking departments of SBP, deposits with SBP, scheduled bank demand deposits, scheduled bank, net foreign assets of SBP etc. are included in the definition of money supply (M1).RER = Real Exchange Rate(is the nominal exchange rate adjusted for differences in prices or inflation rates)

$$
\text { RER }=\text { Nominal Exchange Rate } \times \frac{\text { US: CPI }(2005=100)}{\text { PAK: CPI }(2005=100)}
$$

IR $=$ Interest Rate (simply defined as interbank rate that scheduled bank charge with other banks. FB = Fiscal Balance (the difference of Government revenues and Government expenditures). RGDP $=$ Real Gross Domestic Product (Measures the output produced in any one period or any one year at the prices of some base year. $\varepsilon_{t}$ is the error term of the model.

All the estimation procedure has been done through a computer software E-Views 5.1 version. The estimation procedure consists of number of different steps like checking the stationarity of data, Bound test to check whether the long run relationship among variables exists or not and long run and short run coefficients estimation. All these steps have to be done in a systematic way. These are as follows:

In order to avoid spurious regression results, we will perform the unit root test whether the time series data is stationary or not. If data is stationary at level then we will apply simple OLS method otherwise some other econometric technique e.g. cointegration approach through autoregressive distributed lag (ARDL) model which was developed by (Pesaran et.al 2001).

Co-integration refers to the existence of long run equilibrium relationship between two or more time series variables which are individually non-stationary at their level form Gujrati (1995). A number of co-integration techniques are available to test the existence of long run relationship among variables. The most popular co-integration technique is (Johensen and Jeselius) approach to co-integration (Johansen, 1990) and (Engle-Granger 1987); two-step residual based co-integration. But the new technique with ARDL model has got much 
attention in the recent literature. In this research, ARDL approach is used because of its robustness and general applicability.

ARDL approach is consisted of two stages. In the first stage, the long run relationship between variables is tested using F-statistics to determine the significance of the lagged levels of the variables in the unrestricted error correction model. In the second stage, the coefficient of the long run and short run relationship will be examined. Bounds test approach is used to find the long run relationship among the variables. To do this error correction model will be developed which is applicable when variables are integrated of order I (0), I (1) or combination of both. The unrestricted error correction model for general approach to determinants of balance of payments in the present study will be as:

$$
\begin{aligned}
\Delta \mathrm{BOP}_{\mathrm{t}}= & \alpha_{0}+\sum_{\mathrm{i}=1}^{\mathrm{k}_{1}} \alpha_{1 i} \Delta(\mathrm{BOP})_{\mathrm{t}-\mathrm{i}}+\sum_{\mathrm{i}=0}^{\mathrm{k}_{2}} \alpha_{2 i} \Delta(\mathrm{M} 1)_{\mathrm{t}-\mathrm{i}}+\sum_{\mathrm{i}=0}^{\mathrm{k}_{3}} \alpha_{3 i} \Delta(\mathrm{FB})_{\mathrm{t}-\mathrm{i}}+\sum_{\mathrm{i}=0}^{\mathrm{k}_{4}} \alpha_{4 i} \Delta(\mathrm{IR})_{\mathrm{t}-\mathrm{i}} \\
& +\sum_{\mathrm{i}=0}^{\mathrm{k}_{5}} \alpha_{5 i} \Delta(\mathrm{RGDP})_{\mathrm{t}-\mathrm{i}}+\sum_{\mathrm{i}=0}^{\mathrm{k}_{6}} \alpha_{6 i} \Delta(\mathrm{RER})_{\mathrm{t}-\mathrm{i}}+\beta_{1}(\mathrm{BOP})_{\mathrm{t}-1}+\beta_{2}(\mathrm{M} 1)_{\mathrm{t}-1} \\
& +\beta_{3}(\mathrm{FB})_{\mathrm{t}-1}+\beta_{4}(\mathrm{IR})_{\mathrm{t}-1}+\beta_{5}(\mathrm{RGDP})_{\mathrm{t}-1}+\beta_{6}(\mathrm{RER})_{\mathrm{t}-1}+\varepsilon_{\mathrm{t}}
\end{aligned}
$$

Where $\Delta$ shows the first difference operator and $\varepsilon_{t}$ is the residual of the model which assume to be normally distributed and white noise. In our model, we will use the lagged value of first difference dependent variable and independent variables for short run and first lagged values of dependent and independent variables for long run. So, this model is consisted of both long run and short run coefficients of variables as well. Where $\alpha_{1 \mathrm{i}}, \alpha_{2 \mathrm{i}}, \alpha_{3 \mathrm{i}}, \alpha_{4 \mathrm{i}}, \alpha_{5 \mathrm{i}}$ and $\alpha_{6 \mathrm{i}}$ are the short run coefficients of variables and $\beta_{1}, \beta_{2}, \beta_{3}, \beta_{4}, \beta_{5}$ and $\beta_{6}$ are the long run coefficients of variables and $\alpha_{0}$ is the intercept term.

We will apply Wald coefficient test or joint significance F-test on lagged level variables on the above two models. The computed F-statistics will compare with the Tabulated Fstatistics. The table is developed by (Pesaran et.al 2001). The tabulated F-statistics has two critical bounds, lower bound I (0) and upper bound I (1). If calculated F-statistics is larger than upper bound it means long run relationship existed among the variables. If calculated Fstatistics is less than lower bound long run relationship does not exist and if calculated value is between two bounds the result is inconclusive.

After declaration of the long run relationship among the variables, the next step is to find out the long run coefficients. We will use Akiake Information Criteria (AIC) and SchwartzBayesian (SBC) to choose the optimal lag, the former select maximum and later selects minimum possible long-run. 
We want to see the effects of explanatory variables on balance of payments in case of Pakistan both in the short run and long run. So, to find out the long run and short run coefficients of explanatory variables we have to estimate the model which are given in equations (3 and 4) with OLS (Bound test approach to co-integration) technique and then normalize the resulting values. The ARDL model for the long run coefficient of general approach to determinants of balance of payments will be as.

$$
\begin{aligned}
\mathrm{BOP}_{\mathrm{t}}= & \eta_{0}+\sum_{\mathrm{i}=1}^{\mathrm{k}_{1}} \eta_{1 \mathrm{i}}(\mathrm{BOP})_{\mathrm{t}-\mathrm{i}}+\sum_{\mathrm{i}=0}^{\mathrm{k}_{2}} \eta_{2 \mathrm{i}}(\mathrm{M} 1)_{\mathrm{t}-\mathrm{i}}+\sum_{\mathrm{i}=0}^{\mathrm{k}_{3}} \eta_{3 i}(\mathrm{IR})_{\mathrm{t}-\mathrm{i}}+\sum_{\mathrm{i}=0}^{\mathrm{k}_{4}} \eta_{4 \mathrm{i}}(\mathrm{RER})_{\mathrm{t}-\mathrm{i}} \\
& +\sum_{\mathrm{i}=0}^{\mathrm{k}_{5}} \eta_{5 \mathrm{i}}(\mathrm{FB})_{\mathrm{t}-\mathrm{i}}+\sum_{\mathrm{i}=0}^{\mathrm{k}_{6}} \eta_{6 \mathrm{i}}(\mathrm{RGDP})_{\mathrm{t}-\mathrm{i}}+\varepsilon_{\mathrm{t}}
\end{aligned}
$$

Now we will find the short coefficient of the model with error correction term. We will use the short run error correction estimates of ARDL model. The difference between actual and estimated values is considered as error correction term. Error correction term is defined as adjustment term showing the time required in the short run to move toward equilibrium value in the long run. The coefficient of error term should be negative and significant. If the value of error term is negative and significant it means that there is existence of relationship among variables in the model. The short run error correction model of General Approach to balance of payments is as follows:

$$
\begin{aligned}
\Delta \mathrm{BOP}_{\mathrm{t}} & =\rho_{0}+\sum_{\mathrm{i}=1}^{\mathrm{k}_{1}} \rho_{1 \mathrm{i}} \Delta(\mathrm{BOP})_{\mathrm{t}-\mathrm{i}}+\sum_{\mathrm{i}=0}^{\mathrm{k}_{2}} \rho_{2 \mathrm{i}} \Delta(\mathrm{M} 1)_{\mathrm{t}-\mathrm{i}}+\sum_{\mathrm{i}=0}^{\mathrm{k}_{3}} \rho_{3 \mathrm{i}} \Delta(\mathrm{IR})_{\mathrm{t}-\mathrm{i}} \\
& +\sum_{\mathrm{i}=0}^{\mathrm{k}_{4}} \rho_{4 \mathrm{i}} \Delta(\mathrm{RER})_{\mathrm{t}-\mathrm{i}}+\sum_{\mathrm{i}=0}^{\mathrm{k}_{5}} \rho_{5 \mathrm{i}} \Delta(\mathrm{FB})_{\mathrm{t}-\mathrm{i}}+\sum_{\mathrm{i}=0}^{\mathrm{k}_{6}} \rho_{6 \mathrm{i}} \Delta(\mathrm{RGDP})_{\mathrm{t}-\mathrm{i}}+\lambda(\mathrm{ECM})_{\mathrm{t}-1}+\varepsilon_{\mathrm{t}}
\end{aligned}
$$

$\mathrm{ECM}_{\mathrm{t}-1}$ is lagged error correction term of the model and $\lambda$ is the coefficient value of ECM which is the speed of adjustment.

To interpret the results correctly stability of the parameters we will conduct the test of Cumulative sum of recursive residuals (CUSUM) and cumulative sum of recursive residuals of square (CUSUMS). After that we will conduct some diagnostic tests like J-B normality test to check whether residuals of the model are normally distributed or not. BreuschGodfrey Serial Correlation LM test is conducted to see the autocorrelation problem in the model. Ramsey reset test is conducted to check whether the model is correctly specified or not. 
It has been decided that autoregressive distributed lag (ARDL) model will be used for estimation.

\section{Results and Interpretation}

We have found five determinants of balance of payments that are responsible for fluctuations in the balance of payments. These are money supply, interest rate, real exchange rate, real gross domestic product and fiscal balance deficit. We will examine the effects of these variables on balance of payments by using autoregressive distributed lag model (ARDL)

Since the data is time series therefore unit root test will be conducted in order to check the stationarity in the data and to determine the order of integration whether the variables are stationary at I (0), I (1) or combination of both. Augmented Results of the unit root test by applying ADF test are given in table (1).

Table.1: Stationarity of Variables

\begin{tabular}{|c|c|c|c|c|}
\hline variables & $\begin{array}{lll}\text { Intercept } & \text { /Intercept } & \& \\
\text { Trend/None } & & \end{array}$ & Level & $\begin{array}{l}\text { First } \\
\text { difference }\end{array}$ & $\begin{array}{l}\text { Order of } \\
\text { Integration }\end{array}$ \\
\hline BOP & $\begin{array}{l}\text { Intercept } \\
\text { Intercept and trend } \\
\text { none }\end{array}$ & $\begin{array}{l}- \\
4.787592^{*} \\
- \\
4.710110^{*} \\
- \\
4.830843^{*}\end{array}$ & $\begin{array}{l}6.649123^{*} \\
-6.537514^{*} \\
-6.759216^{*}\end{array}$ & $\mathrm{I}(1)$ \\
\hline M1 & $\begin{array}{l}\text { Intercept } \\
\text { Intercept and trend } \\
\text { none }\end{array}$ & $\begin{array}{l}-2.424801 \\
- \\
1.318956^{*} \\
-1.612064\end{array}$ & $\begin{array}{l}-6.793139^{*} \\
-6.710323^{*} \\
-6.829215^{*}\end{array}$ & $\mathrm{I}(1)$ \\
\hline RER & $\begin{array}{l}\text { Intercept } \\
\text { Intercept and trend } \\
\text { none }\end{array}$ & $\begin{array}{l}0.752134 \\
-2.259905 \\
2.154084\end{array}$ & $\begin{array}{l}-3.716451 * \\
-4.272189 * \\
-2.484152 * *\end{array}$ & $\mathrm{I}(1)$ \\
\hline IR & $\begin{array}{l}\text { Intercept } \\
\text { Intercept and trend } \\
\text { none }\end{array}$ & $\begin{array}{l}-2.358265 \\
-2.260721 \\
-0.357609\end{array}$ & $\begin{array}{l}-4.348620^{*} \\
-4.528627^{*} \\
-4.417672^{*}\end{array}$ & $\mathrm{I}(1)$ \\
\hline FB & $\begin{array}{l}\text { Intercept } \\
\text { Intercept and trend } \\
\text { none }\end{array}$ & $\begin{array}{l}-1.194055 \\
-2.306238 \\
-0.703910\end{array}$ & $\begin{array}{l}-3.6422 * * \\
-4.2605 * \\
-3.6344 *\end{array}$ & $\mathrm{I}(1)$ \\
\hline
\end{tabular}




\begin{tabular}{|l|l|l|l|l|}
\hline RGDP & Intercept & 0.211074 & $-3.708639 *$ & $\mathrm{I}(1)$ \\
& Intercept and trend & -1.122830 & $-3.980442 * *$ & \\
& none & 0.904638 & $-3.459283 *$ & \\
\hline \multicolumn{2}{|c|}{$, * *, * * *$ indicate $1 \%, 5 \%$ and $10 \%$ level of significance. }
\end{tabular}

It shows BOP at $\mathrm{I}(1), \mathrm{M} 1$ at $\mathrm{I}(1), \mathrm{RER}$ at $\mathrm{I}(1), \mathrm{IR}$ at $\mathrm{I}(1), \mathrm{FB}$ at $\mathrm{I}(1)$ and $\mathrm{RGDP}$ at $\mathrm{I}(1)$ are stationary at these order of integration. Our finding of time series data shows that our variables are stationary with the combination of I (1). So, in this case Johesan co-integration technique can be applied but we will handle the issue by some advanced technique: the Bounds testing approach or autoregressive distributed lag (ARDL) model which was developed by (Pesaran et.al 2001) because it is suitable for smaller sample. These results of the model are given in annexure table (1) by estimating the equation (1) of determinants of balance of payments by using OLS. The results of our model show most of the variables are significant and few are insignificant. After confirming the order of integration of variables we have conducted the Bound test or Wald test to see whether the long run relationship among the variables exists or not. We will follow the Bound testing approach and restrict all long run coefficients equal to zero in our null hypothesis.

The Bound test result is given in the following table.

Null Hypothesis: $\quad \beta_{1}=\beta_{2}=\beta_{3}=\beta_{4}=\beta_{5}=\beta_{6}=0 \quad$ (No Co-integration Exist)

Alternative Hypothesis: $\quad \beta_{1}=\beta_{2}=\beta_{3}=\beta_{4}=\beta_{5}=\beta_{6} \neq 0 \quad$ (Co-integration Exist)

Table 2: Bound Test Result

\begin{tabular}{|l|l|l|l|l|}
\hline Variables & $\begin{array}{l}\text { F- } \\
\text { statistic }\end{array}$ & $\begin{array}{l}\text { Critical } \\
\text { Value I(0) \& } \\
\text { I(1) }\end{array}$ & $\begin{array}{l}\text { Probabilit } \\
\mathbf{y}\end{array}$ & $\begin{array}{l}\text { Co- } \\
\text { integration }\end{array}$ \\
\hline $\begin{array}{l}\text { Determinan } \\
\text { ts of BOP }\end{array}$ & 17.38 & $\begin{array}{l}\mathrm{I}(0)=3.636, \\
\mathrm{I}(1)=4.267\end{array}$ & 0.000 & $\begin{array}{l}\text { Co- } \\
\text { integration } \\
\text { exist }\end{array}$ \\
\hline
\end{tabular}

The F-statistics value is greater than upper bound value $I(1)=4.267$ and this indicates that we can reject the null hypothesis. So, it is found that there exists long run relationship among the variables used in our model. 
Table 3: Diagnostic Tests

\begin{tabular}{|l|l|l|}
\hline Test & Statistics & Probability \\
\hline JERQUA-BERRA NORMALITY TEST & 1.25 & 0.53 \\
\hline BREUSH-GODFREY SERIAL CORREALTION LM TEST & 0.69 & 0.51 \\
\hline ARCH TEST HETEROSKEDASTICITY & 2.23 & 0.14 \\
\hline RAMSEY RESET FOR MISSPECIFICATION TEST & 0.69 & 0.41 \\
\hline
\end{tabular}

The absence of divergence in CUSUM and CUSUMS graphs confirms in our ARDL estimation, short run and long run estimates are stable.

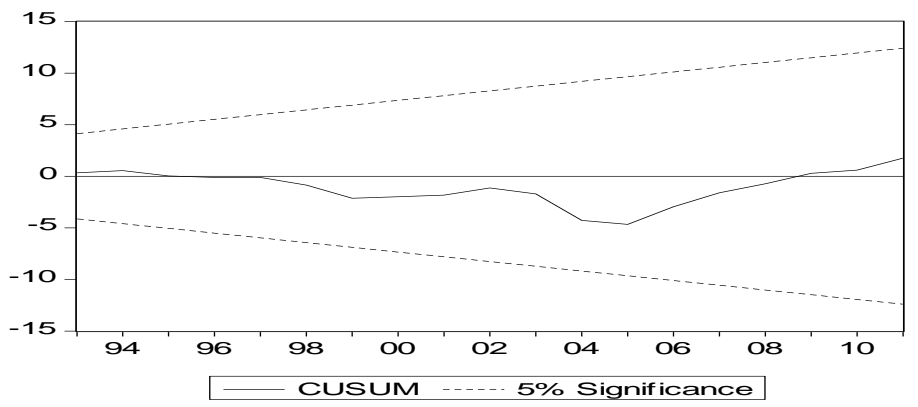

Figure 4: Stability Test: Cumulative Sum of Recursive Residuals (CUSUM)

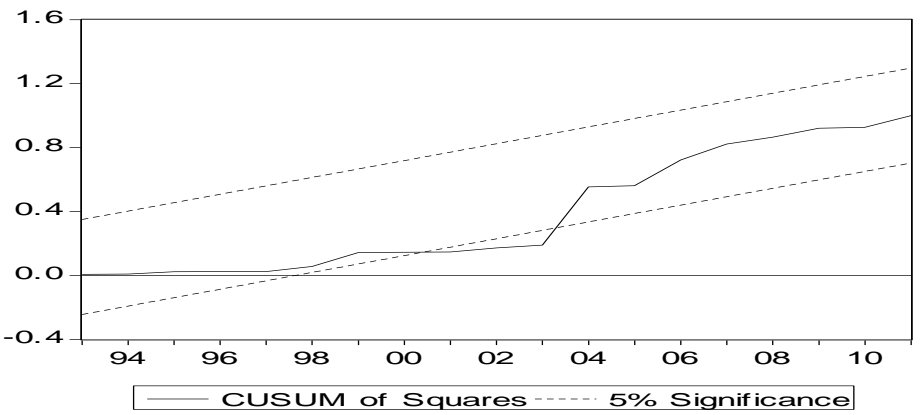

Figure 5: Stability Test: Cumulative Sum of Squares of Recursive Residuals (CUSUMSQ)

In order to determine long run co-efficient we use the normalization process in which all lagged co-efficient of all explanatory variables are divided by co-integration vector after multiply it (-1). The results are reported in the table below. 
Table 4: Normalized Long run Estimates (Dependent Variable: $\Delta \mathrm{BOP}$ )

\begin{tabular}{|c|c|c|}
\hline Variables & Co-efficient & P-value \\
\hline M1(-1) & $(0.297987)^{* *}$ & 0.0229 \\
\hline $\operatorname{RER}(-1)$ & $(-242.878)$ & 0.8941 \\
\hline $\operatorname{IR}(-1)$ & $(-20107.8) * *$ & 0.0467 \\
\hline $\mathrm{FB}(-1)$ & $(-0.61017)$ & 0.1628 \\
\hline $\operatorname{RGDP}(-1)$ & $(0.09686) * *$ & 0.0582 \\
\hline
\end{tabular}

The results in table 4 indicate that the long run coefficients show that money supply (M1), real gross domestic product and interest rate are the main determinants of balance of payments. Coefficient value of money supply is 0.297987 which means that in the long run a one million rupee increases in money supply will cause a 0.297987 million rupees increase in the overall surplus of balance of payments. The value of money supply coefficient is positive and significant. This result matches with that of (Duasa 2004), (Eita 2012) and (Trunin 2012) .The monetarist argue that money supply is positively related to overall balance of payments and sustainable growth rate of money supply is beneficial for the overall betterment of macroeconomic variables

Real exchange rate is found to be insignificant and negative although the sign of real exchange rate variable is contrary to the theory. A decrease in the exchange rate or devaluation in the currency makes the export cheap and imports expensive and hence overall trade balance will be improved in the long run. But in this study real exchange rate is found to be negative and insignificant in the long run. Although it is contrary to economic theory but being a developing country it is justifiable. The justification of this result is that the exchange rate is found to be negative and insignificant in case of developing countries like Pakistan because Marshal-Lerner condition does not fulfill in developing countries. Further the phenomenon of J-curve is hardly seen in developing countries. Developing countries are supply oriented rather than demand oriented. This result is matched to that of (Khan 2008), (Felipe et.al 2009), (Umer et.al 2010) and (Eita 2012). This is confirmation that our result in this regard is not unexpected and novel. 
Interest rate is found to be negative and significant in the long run. A one percent increases in the interest rate will cause the 20107.8 million rupees decrease in the overall balance of payments .The negative sign of interest rate matches with economic theory. Interest rate and investment are negatively related as interest rate increases the cost of capital increases or investment is discouraged hence domestic production will become more expensive to produce resulting in its reduction. Lower domestic production leads to lower exports revenue which in return causes deficit in current account and consequently overall balance of payments will be distorted. Furthermore, if high interest rate is unable to attract portfolio investment then the situation is worsened. It is what Pakistan is facing in the last or so decade due to spate of terrorism. . This result is harmonized with that of (Dhliwayo 1996), (Choudhary and Shabbir 2005), (Fleermuys 2005), (Adamu and Itsede 2010), (Umer et.al $\underline{2010}$ ) and (Ali 2011).

Fiscal deficit is found to be negative and insignificant. It means that it has negligible impact on the balance of payments in the long run. Government spending has no effect on real macroeconomic variables in the long run (Classical School of Thought). So, the insignificance of government spending in the long run is quite understandable.

Real gross domestic product is found to be positive and significant in the long run. A one million rupee increase in the real gross domestic product will cause the 0.09685 million rupees increase in the overall balance of payments. Real gross domestic product is positive and significant which justifies the economic theory that increases in real income will increase the exports and better will be the balance of trade account (absorption approach). This empirical result is matched with that of (Dhliwayo 1996), (Hernan 1998), (Choudhary and Shabbir 2005), (Fleermuys 2005), (Duasa 2004), (Felipe et.al 2009), (Korsu 2009), (Adamu and Itsede 2010), (Umer et.al 2010), (Eita 2012), (Trunin 2012).

In order to determine the short run estimates, we first develop data for error correction term which is the difference between actual and estimated values. Then we have estimated the model applying the least square method, considering all desirable lags. So, after applying OLS on model equation (4), results are depicted in table (5). 
Table 5: Short Run Estimated Model (Dependent Variable: $\triangle \mathrm{BOP}=\mathrm{D}(\mathrm{BOP})$

\begin{tabular}{|l|l|l|l|l|}
\hline Variable & Coefficient & Standard error & T-value & P-value \\
\hline C & 115565.7 & 17417.02 & 6.635216 & 0.0000 \\
\hline D(RER) & $(-1674.543)$ & 3361.730 & -0.498119 & 0.6229 \\
\hline D(IR) & $(9361.921)^{* *}$ & 4492.861 & 2.083733 & 0.0480 \\
\hline D(IR(-1)) & $(14176.33)^{*}$ & 4634.967 & 3.058560 & 0.0054 \\
\hline D(M1(-1) $)$ & $(-0.948045)^{*}$ & 0.100874 & -9.398353 & 0.0000 \\
\hline D(RGDP) & $(0.111883)^{*}$ & 0.016659 & 6.716066 & 0.0000 \\
\hline D(FB) & $(-1.265959) *$ & 0.147488 & -8.583462 & 0.0000 \\
\hline D(FB(-1)) & $(2.586887)^{*}$ & 0.217345 & 11.90224 & 0.0000 \\
\hline D(BOP(-1)) & $(0.896037)^{*}$ & 0.081345 & 11.01529 & 0.0000 \\
\hline ECM(-1) & $\mathbf{( - 0 . 7 6 6 8 8 6})^{*}$ & $\mathbf{0 . 0 8 3 8 8 6}$ & $\mathbf{- 9 . 1 4 2 0 1 3}$ & $\mathbf{0 . 0 0 0 0}$ \\
\hline
\end{tabular}

Note: $(*, * *$ indicate significant at $1 \%$ and $5 \%$ level respectively).

\begin{tabular}{|l|l|l|l|}
\hline R-squared & 0.976265 & Adjusted R-squared & 0.967364 \\
\hline AIC & 24.15567 & SBC & 24.60460 \\
\hline F-statistics(Probability) & $109.6828(0.000)$ & Durbin-Watson statistics & 2.025178 \\
\hline
\end{tabular}

The results in table (5) show that real exchange rate is found to be negative and insignificant which means it has negligible impact on overall balance of payments. Although it is contrary to the theory because the expected sign of real exchange rate should be positive and significant as the increase in the exchange rate or devaluation in the currency improve the trade balance account as the exports become cheap and imports become expensive. It is without exaggeration to announce that exchange rate is found to negative and insignificant in case of developing countries like Pakistan because Marshal-Lerner condition is not satisfied in developing countries. Developing countries are supply-oriented rather than demand oriented. So, this result is justifiable and not unexpected and matches with that of (Khan 2008), (Felipe et.al 2009), (Umer et.al 2010) and (Eita 2012).

Interest rate is found to be positive and significant in the short run. Its coefficient value is 9361.921 which means that one percent increase in the interest rate will improve the balance of payments by 9361.921 million rupees and is significant. The first lag value of its coefficient is 14176.33 which means one percent increase in the interest rate will improve the balance of payments by 14176.33 million rupees after one lag period. The value of interest rate's coefficient also matches with economic theory because balance of payments is consisted of three accounts current account, capital account and financial account. Although 
increase in the interest rate will distort the current account as increase in the interest rate reduce the domestic production and hence current account will be distorted. But on the other hand as the interest rate increases it will attract the capital inflow and overall balance of payments will be improved. So, the positive sign of interest rate is reasonably understandable.

Money supply is found to be negative and significant. Its coefficient value is -0.948045 which means that a one million rupee increases in the money supply will adversely (negatively) affect the balance of payments by -0.948045 million rupees. This result matches with economic theory. Monetary base is equal to the sum of international reserves and domestic assets holding of monetary authorities. A change in the international reserves will change the money supply. If in any case, people demand for money is greater than its supply then excess demand will be met by the inflows of money from abroad and overall balance of trade will be improved. On the other hand, if supply of money is greater than the demand for money the excess supply will outflow to other countries and overall balance of trade will be distorted. This result tallies with the result of (Dhliwayo 1996), (Hernan 1998), (Choudhary and Shabbir 2005), (Fleermuys 2005), (Duasa 2004), (Felipe et.al 2009), (Adamu and Itsede 2010), (Umer et.al 2010), (Waliullah 2010), (Ali 2011).

Real gross domestic product is positive and significant which matches with economic theory. The value of its coefficient is 0.111883 which means that a one million rupees increase in the real gross domestic product will improve the balance of payments by 0.112 million rupees and is highly significant. Hence, RGDP is declared as major determinant of balance of payments. Increase in real income will increase the exports and better will be the trade balance account (Absorption approach). Real gross domestic product is found to be positively related to BOP and significant (Dhliwayo 1996), ( Shabbir 2005), (Fleermuys 2005), (Duasa 2007), (Felipe et.al 2009), (Korsu 2009), ( and Itsede 2010), (Umer et.al 2010), (Eita 2012), and (Trunin 2012).

Fiscal balance deficit is found to be negative and significant. The coefficient value of fiscal deficit is -1.27 which means that a one million rupees increase in the fiscal deficit will adversely(negatively) affect the balance of payments by -1.27 million rupees and its coefficient value is significant which this indicates fiscal deficit as major determinant of balance of payments. Deficit financing through credit creation/foreign debt is harmful because increase in money supply will cause outflow and overall balance of payments will be in deficit (Choudhary and Shabbir 2005) and (Korsu 2009). Many studies have found the phenomenon of twin deficit (simultaneous deficit in current account and fiscal budget). So, budget deficit is negatively related to overall balance of payments, this result matches with that of Hashemzadeh (2006). 
The error correction term is negative (-0.76) and statistically highly significant i.e. having right sign (negative). This indicates the presence of cointegration among variables which means in each year determinants of balance of payments will be corrected by $76 \%$ with high speed of adjustment to equilibrium following short run shocks i.e. it Points out a high rate of convergence to equilibrium, which denotes that deviation from the long-term equilibrium is corrected by $76 \%$ over each year.

\section{Conclusion and Policy Implication}

This study has been an attempt to find out the determinants of balance of payments. Money supply, real exchange rate, interest rate, fiscal balance and real gross domestic product are found to be major determinants of balance of payments. The analysis was done by taking annual time series data for the period of 1972 to 2013, using ARDL or Bounds testing approach. The study has proved that the balance of payments and its determinants keep both long run and short run relationship.

As far as General Approach (including monetary and other variables) to balance of payments is concerned, it is found that coefficient of money supply is found to be positive in the short run but negative in the long run. So, money supply is most important because it has its impact on BOP. A sustainable growth rate of money supply is required for the improvement of BOP. As Real exchange rate as a determinant of BOP is found to be positive in the short run whereas in the long run, it is negative. It actually indicates that in the short run increase in the interest rate will attract the capital inflow and as a result BOP will improve because it works through NFA (net foreign assets) channel. So exchange rate will improve and BOP will be positively affected. As the time passes on, the exports become expensive and imports cheaper, the graph of exports (earning of a country) decreases and graph of imports increases which emerges as the cause of BOP deterioration. Hence in the long run it has adverse effect on overall balance of payments. In a developing country like Pakistan the increase in the interest rate will inversely affect its balance of payment. As interest rate increases the new investment will decline and hence domestic production will decline.

Fiscal balance negatively affects the balance of payments in short run. But lag value of fiscal balance is found to be positive and significant. In the history of Pakistan, fiscal balance always remained in deficit. In short run increase in expenditure improves the output and overall balance of payments also improves but in the long run fiscal balance is found to be negative.

Real gross domestic product is also one of the most important determinants of balance of payments. Its effect on BOP is positive and significant both in short run and long run. As we 
know RGDP (Real Gross Domestic Product) is the value of all final goods and services which are produced in a year by taking prices of some base year. As the value of real gross domestic product increases, exports increases and current account will be in surplus and consequently overall balance of payments will be improved.

It is here by suggested that measures should be taken to improve the balance of payment of Pakistan. The government of Pakistan should design such policies that its exports should increase.

Central bank of Pakistan has to be vigilant towards its monetary policy and has to take some favorable measures to control the money supply. It has to keep an eye on interest rate and charge low interest rate to encourage the new internal investor

Attainment of balance of payment surplus is difficult but not unreachable. It can be reached through installing import substitution and export promoting industries. Government should control the foreign exchange and ban or at least minimize the import of luxuries. 


\section{References:}

Adamu, A. Patrica., Itsede, C. Osi (2010). Balance of Payments Adjustment: The West African Monetary Zone Experience. West African Journal of Monetary and Economic Integration, Vol. 10. NO.2, 100-116.

Alexander, S.S (1952). Effects of a Devaluation on a Trade Balance. International Monetary Fund Staff Papers, 2, 263-278.

Ali, G (2011). Pakistan's Balance of Payments as a Monetary Phenomenon: (Econometric Evidence). Journal of Managerial Science. Vol.5, No.2, 168-178.

Alvarez-Ude, F., Guadalupe, Galvez, M., Isis, Gomez, M., David. (2008). Empirical Evidence of the Balance of Payments Constrained Growth in Cuba. The Effects of Comercial regimes since 1960. Munich Personel Repec Archive Research Paper. No.6993, University Library of Munich, Germany.

Asteriou, D (2006). Applied Econometrics: A Modern Approach Eviews. McGraw-Hill Publishers. 297-303.

Baluch, A.Khurram., Bukhari, H.K.Syed (2012). Price and Income Elasticity of Imports: The case of Pakistan. State Bank of Pakistan, Working paper series.No.48.

Choudhary, A. Mohammad., Shabbir, G (2005). Macroeconomic Impact of Budget Deficit on Pakistan Foreign Sector. Pakistan Economic and Social Review, Vol.XLIII,No. 2, 185198.

Choudhary, A.M., Shabbir, G (2005). Macroeconomic Impact of Monetary Variables on Pakistan's Foreign Sector. The Lahore Journal of Economics Vol. 9, NO. 1, 63-84.

Dickey, D.A. and W.A. Fuller (1979). Distribution of the Estimators for Autoregressive Time Series with a Unit Root. Journal of the American Statistical Association, 74, 427-31.

Duasa, J (2004). The Malaysian Balance of Payments: Keynesian Approach versus Monetary Approach. Global Economic Review, Perspective on East Asian Economies and Industries, Vol. 37, No.1.

Dhliwayo, R (1996). The Balance of Payments as a Monetary Phenomenon: An Econometric Study of Zimbabwe's Experience. African Economic Research Consortium, Research Paper 46, Nairobi.

Eita, H. Joel., Gaomab, H. Mihe (2012). Macroeconomic Determinants of Balance of Payments. International Journal of Business and Management, Vol. 07, No. 3, 173-184. 
Engle, R.F., and C.W.J. Granger (1987). Co-Integration and Error Correction: Representation, Estimation and Testing. Econometrica, 55, 251-76.

Fida, A.Bashir., Zakaria, M., Hashmi, M.Shabir (2009). Balance of Payments Constrained Growth Model: A case study of Pakistan. European Journal of Scientific Research, Vol. 25, No. 4, 574-583.

Falk, M (2008). Determinants of the Trade Balance in Industrialized Countries. FIW Austrian Working Paper.

Felipe, J., Maccombie, Naqvi, K (2009). Is Pakistan Growth Rate Balance of Payments Constrained? Policies and implications for Development and Growth. Asian Development Bank Economics, Working Paper Series. NO 160.

Fleermuys, N. F (2005). The balance of payments as a monetary phenomenon: An econometric study of Namibia. DEA Working Paper series.

Gujarati, N. Damodar (1995). Basic Econometrics. New Yark: McGraw- Hill.

Hernan, C. Rincoc (1998). Testing the Short Run and Long Run Exchange Rate Effects on Trade Balance: The Case of Colombia. Ph.D Disertation at University of Illionoiss at Urbana-Champaign.

Johansen, S., and K. Juselius (1990). Maximum Likelihood Estimation and Inference on Cointegration with Application to the Demand for Money. Oxford Bulletin of Economics and Statistics, 52, 169-210.

Khan, M. Arshad (2008). Long- Run and Short-Run Dynamics of Foreign Reserves and Domestic Credit in Pakistan. International Journal of Applied Economics and Quantitative Studies, Vol. 5, No. 1, 61-84.

Korsu, D. Robert (2009). Fiscal Deficit and the External Sector Performance of Sierra Leone: A Simulation Approach. Journal of Economics and Monetary Integration, Vol. 9, No. 1, 51-73.

Krugman R. Paul and Obstfeld, Maurice (1998). International Economic Theory and Policy. Fourth Edition, Addison Wesley Longman.

Mohammad, D. Sulaiman (2010). Determinants of Balance of Trade: Case Study of Pakistan.” European Journal of Scientific Research, Vol. 41, No. 1, 13-20. 
Mundell, RA (1971). Monetary Theory: Inflation, Interest and Growth in the World Economy. Pacific Palisades: Goodyear.

Narayan, P.K. (2004). Reformulating Critical Values for the Bounds F-statistics Approach to Co-integration: An Application to the Tourism Demand Model for Fiji. Discussion Papers, Department of Economics, Monash University, Australia.

Pesaran, H.M., and Shin, Y. (1999). Autoregressive Distributed Lag Modeling Approach to Co-integration Analysis, Chapter 11, in Storm, S., (ed.), Econometrics and Economic Theory in the $20^{\text {th }}$ Century: The Ragnar Frisch Centennial Symposium. Cambridge University Press: Cambridge.

Pesaran, H.M., Shin, Y. and Smith, R.J (2001). Bounds Testing Approaches to the Analysis of Level Relationships. Journal of Applied Econometrics, 16, 289-326.

Rehman, H,. Rashid, A. Hafiz (2006). The Balance of Payments Problem in Developing Countries, Especially in Pakistan.” The Journal of Commerce, Vol.1, No. 1, 31-52.

Rano, U. Shehu., Aliyu (2008). Imports -Exports Demand Function and Balance Payments Stability in Nigeria: A Co-integration and Error Correction Modeling. Munich Personel Repec Archive Research Paper. No.10396.

Robinson, J. (1937). Essays in the Theory of Employment. Oxford: Basil Blackwell.

Silumbu, D. B. Exley (1995). The Role of Exchange Rate and Monetary Policy in the Monetary Approach to the Balance of Payments: Evidence from Malawi. African Economic Research Consortium, Research Paper. No. 37.

Trunin, P (2012). An Analysis of the Impact of the Balance of Payments Capital Account on Macroeconomic Processes in Russian Federation.

Umer, M., Muhammad, D. Sulaiman., Abro, A. Asif., Sheikh, A. Qurra-Tul-Ain., Ghazali, A (2010). The Balance of Payments as a Monetary Phenomenon Econometric Evidence from Pakistan. International Research Journal of Finance and Economics, Issue 38, 210-218.

Vernengo, M (2003). Balance of Payments Constraint and Inflation. University of Utah Department of Economics Working Paper Series No. 2003-06.

Waliullah, Kakar, K. Mehmood., Kakar, R., Khan, W (2010). The Determinants of Pakistan's Trade Balance: An ARDL Co-integration Approach. The Lahore Journal of Economics, Vol. 15, No.1, 1-26.Zaidi, S. Akbar (2005). Issues in Pakistan's Economy. $2^{\text {nd }}$ Edition, Oxford University Press. 


\section{Annexure}

Table.1: Dependent variable: $\triangle \mathrm{BOP}$

(General Approach to BOP)

\begin{tabular}{|l|l|l|l|l|}
\hline Variables & Coefficient & Standard Error & T-value & P-value \\
\hline C & 149646.0 & 93181.64 & 1.605961 & 0.1248 \\
\hline D(RER) & $(-1553.023)$ & 3925.128 & -0.395662 & 0.6968 \\
\hline D(IR) & $(10242.55)$ & 6469.509 & 1.583204 & 0.1299 \\
\hline D(IR(-1)) & $(19136.22)^{* *}$ & 8080.467 & 2.368207 & 0.0286 \\
\hline D(M1(-1)) & $(-1.184591)^{* *}$ & 0.430209 & -2.753528 & 0.0126 \\
\hline D(RGDP) & $(0.104942)^{*}$ & 0.023440 & 4.477069 & 0.0003 \\
\hline D(FB) & $(-1.114954)^{*}$ & 0.260952 & -4.272640 & 0.0004 \\
\hline D(FB(-1)) & $(2.720763)^{*}$ & 0.472847 & 5.753999 & 0.0000 \\
\hline D(BOP(-1)) & $(0.862111)^{*}$ & 0.191356 & 4.505273 & 0.0002 \\
\hline BOP(-1) & $(-0.717437)^{*}$ & 0.213362 & -3.362538 & 0.0033 \\
\hline RER(-1) & $(-174.2507)$ & 1292.162 & -0.134852 & 0.8941 \\
\hline IR(-1) & $(-14426.16)^{* *}$ & 6781.384 & -2.127318 & 0.0467 \\
\hline M1(-1) & $(0.213788)^{* *}$ & 0.086392 & 2.474628 & 0.0229 \\
\hline RGDP(-1) & $(0.069493)^{* *}$ & 0.034474 & 2.015829 & 0.0582 \\
\hline FB(-1) & $(-0.437758)$ & 0.301447 & -1.452188 & 0.1628 \\
\hline
\end{tabular}

$*, * *$ are indicating coefficient is significant $1 \%$ and $5 \%$ level respectively.

\begin{tabular}{|c|l|l|l|}
\hline R-Squared & 0.977175 & Adjusted R-Squared & 0.960357 \\
\hline AIC & 24.41067 & SBC & 25.08406 \\
\hline F-statistic(probability) & $58.10192(0.000)$ & D-W statistic & 2.068406 \\
\hline
\end{tabular}

